\title{
Lifelong Learning and ESP Vocabulary: Reflections in Telecommunications and ICT
}

\begin{abstract}
This paper examines the building of a glossary of technical terms by a sample of master's degree students in the professional field of Telecommunications Engineering. To achieve this aim, linguistic data was extracted from the European MACbioIDi INTERREG Project with the aim of creating a collaborative bilingual, English-Spanish glossary. The glossary is used to foster vocabulary learning strategies for ELF/ESP learners and teachers of English. The study, designed for lifelong learning education and set in an ESP context of ICT and Telecommunications, shows (i) how a glossary building task can take the form of collaborative and reflective vocabulary learning projects in ESP, (ii) the learners' identification of anglicisms in their professional domains, and (iii) samples of writing products stemming from building the glossary.
\end{abstract}

Keywords: ELF, ESP, vocabulary, lifelong learning, professional English

\section{Vseživljenjsko učenje besedišča angleščine kot jezika stroke: Refleksije na področju telekomunikacij in IKT}

POVZETEK

Prispevek proučuje glosar strokovnih izrazov, ki so ga sestavili magistrski študenti telekomunikacijskega inženiringa. Za ta cilj smo iz evropskega projekta MACbioIDi INTERREG pridobili jezikovne podatke, s katerimi smo ustvarili kolaborativni, dvojezični angleško-španski glosar. Glosar smo uporabili, da bi razvili strategije učenja besedišča pri študentih in učiteljih angleščine kot lingue france in angleščine kot jezika stroke. Študija, zasnovana za vseživljenjsko izobraževanje in umeščena v okolje jezika stroke na področju IKT in telekomunikacij, je pokazala: i) da je lahko sestavljanje glosarja kolaborativna in reflektivna besediščna dejavnost pri poučevanju jezika stroke; ii) kako študenti prepoznajo anglicizme na svojem strokovnem področju, in iii) primere pisnih izdelkov, ki izhajajo iz sestavljanja glosarja.

Ključne besede: angleščina kot lingua franca, angleščina kot jezik stroke, besedišče, vseživljenjsko učenje, poklicna angleščina 


\section{Introduction and Context}

This study emerges from the European Project Interreg - MAC 2014-2020 "Promoting the cohesion of the Macaronesian ORs, through a common ICT platform for biomedical $\mathrm{R}+\mathrm{D}+\mathrm{I}$ " (with the acronym MACbioIDi). ${ }^{1}$ The main goal of the project is to develop medical technology and educational programs, paying attention to social and business transfer.

The multilingual project team, coordinated by the Universidad de Las Palmas de Gran Canaria, was formative-oriented and consisted of multilingual researchers specializing in applied linguistics and ICT for language learning. Their cooperation resulted in a multilingual formative wiki "Medical Technology for the Sustainable Development", which is adapted to the languages of the project (Arabic, English, French, Portuguese and Spanish). The wiki acts as a training support for the territories involved and for anyone interested in the topics of medical technology for sustainable development (see Figure 1).

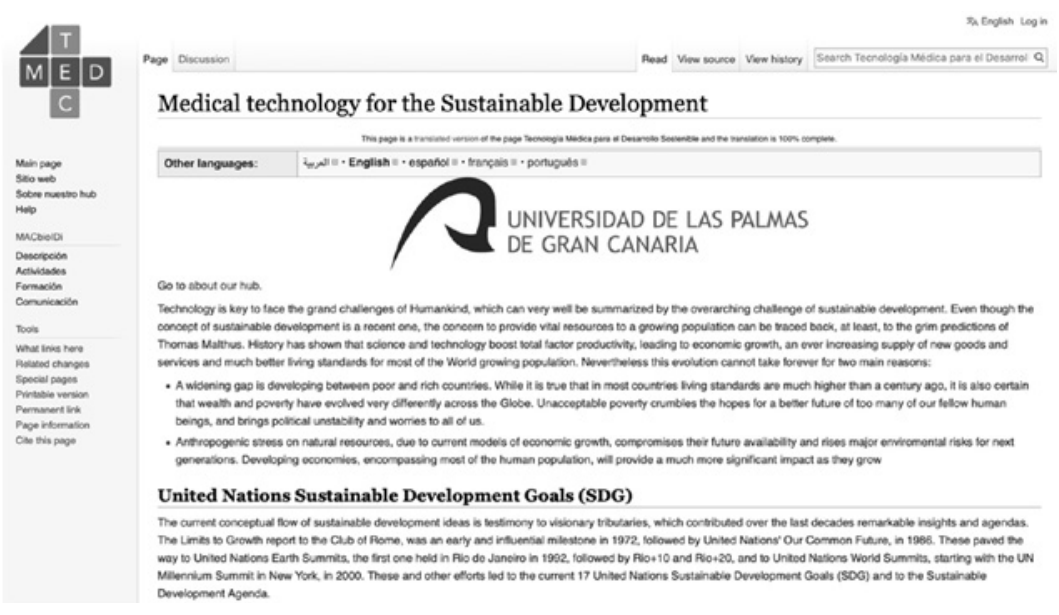

Figure 1. MedTec Formative Wiki in English.

For lifelong learners, maintaining a level of education and technological skills is key to potential job opportunities. A 21 st-century citizen requires constant learning and adapts their knowledge, skills and behaviors to the constant changes not only in education, but in technological, cultural and social contexts (Loveless and Williamson 2012). This also means that efficient lifelong learners use English for Specific Purposes (ESP) in global and/or professionally oriented situations and that accurate and up-to-date vocabulary is necessary to successfully convey messages (Bourn 2018; Conole and Paredes 2018).

This research is based on the use and understanding of ESP vocabulary in a ubiquitous lifelong English learning environment, set in tertiary education. This setting combines English for Specific Purposes (ESP) and English as a Lingua Franca (ELF), since learners

\footnotetext{
The ORs refers to Ultraperipheral Regions. MACbioIDi has 31 partners in the Canary Islands, Madeira, the Azores, Cape Verde, Mauritania, Senegal, mainland Spain and the USA. The project has several objectives, including promoting research and mitigating technological development and innovation for sustainable development (MedTec4SusDev).
} 
gather lexical terms or phrases from various tools and resources planned for the onsite course (texts, online platforms, research journals...) and from various hybrid forms of formal and informal learning. Moreover, participating in ubiquitous learning has had a big influence on informal language learning, since instant and contextualized responses happen anywhere and at any time, such as by simply connecting one's smartphone to the internet (Elsafi 2018; Enos, Kehrhahn, and Bell 2003; García-Sánchez and Burbules 2017).

Our initial hypothesis is that the natural link between formal and informal learning in higher education enhances students' language skills that can be employed in genuine workplace scenarios, and that the MedTec Formative Wiki presented above serves as a tool for this purpose. The English language (EL) tertiary education learner is trained to become a lifelong learning international professional, so ESP and ELF situations are a necessity in formal and informal learning environments.

The present research is based on the following research questions (RQ).

RQ1. What collaborative and reflective dimensions have been implemented to elaborate the MACbioIDi glossary with the expressions known and/or used by Spanish ESP students of telecommunications engineering?

RQ2. From the learners' reflective perspective, what professional English terms, considered anglicisms, have been adapted in Spanish according to the seven subtopics of the MACbioIDi glossary?

RQ3. What examples of ESP vocabulary have students used productively in a lifelong learning education?

\section{Literature Review}

\subsection{Informal vs. Formal Learning for the English Language}

English vocabulary acquisition enhances learners' EL skills. This achievement in foreign language knowledge is linked not just to reading and writing, but to other language skills such as listening and speaking. Information and Communication Technology (ICT) resources have improved EL learners' access to specific terminology and/or contextualized real-life expressions (Elgort 2018; Peters and Webb 2018). This natural, instant and unplanned informal learning, which often includes intrinsic and personal motivation, can significantly develop students' self-study, curiosity and pronunciation skills in English. It also allows learners to combine their natural learning style with the set plan for their EL courses in higher education, and thus improve their strategies in knowledge building and language acquisition (formal learning), which may include both intrinsic and extrinsic motivation (Ardeo González 2016; Illeris 2010; Navickienè, Kavaliauskienė, and Pevcevičiūtė 2015).

Higher education, especially when dealing with responsible and autonomous learners working on their master's degrees, is supported by the combination of formal and informal learning. Both forms can take place in face-to-face learning and in ubiquitous learning ecologies that happen anywhere at any time, although the former most often happens inside the classroom 
while the latter could happen inside and outside the classroom (Cope and Kalantzis 2017; García-Sánchez and Luján-García 2016). Formal learning is tied to the content and abilities driven by the curriculum, but quite often it also intertwines with unconscious and motivated pieces of information the learner wishes to achieve. García-Sánchez $(2017,2016)$ demonstrated that learners are already used to ubiquitous learning experiences that combine formal and informal learning settings owing to the internet, global information provided in English, and a variety of ICT resources for learning. Other researchers have connected informal learning with the workplace (e.g., Rutherford 2017), while Rienties and Kinchin (2014) also claim that both learning environments (formal and informal) complement each other. In addition, Latchem $(2016,180)$ reported that informal learning is "ongoing, voluntary and self-motivated", which also supports the link between informal and lifelong learning. The relationship between intrinsic and extrinsic motivation, or between personal or professional learning, should thus be well-planned in ESP lifelong learning language programs in higher education.

\subsection{English as a Lingua Franca for Professional Language Growth}

English as a Lingua Franca (ELF) for professional development also falls within the wider subject of lifelong learning (Crystal 2012; Dewey 2014; Jenkins 2015; Yano 2009) and multimodal ubiquitous learning practices. Advances in Teaching English as a Foreign Language (TEFL), English for Specific Purposes (ESP) or English as an International Language (EIL) have had positive effects on the enhancement of accurate professional language, which, at the same time, is linked to everyday expressions that the learner acquires from various situations and resources (Fraiberg 2018; McKay and Bokhorst-Heng 2017). The access to ubiquitous information, anywhere and at any time, and quite often through ICT, allows EL learners to get updated lexis and be exposed to various EL contexts that can be related also to their professional environments (Duff 2017; Ferguson 2007; McIntosh, Connor, and GokpinarShelton 2017).

ESP vocabulary, definition structures, information to perform different language tasks/skills in English, and reflective learning achievements are not seen as isolated when designing a lifelong ESP learning course. They are carefully intended to foster interaction and achieve communicative goals in higher education. Mishan (2004) states that the use of language for communication can have different purposes, such as informing, persuading, comparing, analyzing or reporting. To train telecommunications engineers in authentic professional tasks, not only specific content and vocabulary need to be acquired, but they also need to enhance their teamwork abilities, so that the data can be planned, collected and presented effectively. This process not only requires reflective practice related to individual/team learners' language skills, but also other real-life, cultural abilities that help students communicate with an international professional audience (ELF).

Furthermore, in a reflective practice EL students need to understand, firstly, the goals, and, secondly, how to meet them. To quote Duff $(2017,508)$ : "Language socialization refers to the acquisition of linguistic, pragmatic and other cultural knowledge through social experience and is often equated with the development of cultural and communicative competence." 
Lifelong learning participants need to receive such socialization when learning English as an international and professional language. Professionals should be aware that English is the global language that links their professions and their lifelong learning (Belcher 2006; Kassim and Ali 2010; Kennedy 2012). Consequently, their vocabulary should be current and accurately used, especially when ESP is produced in a professional environment.

\subsection{International Professional English and Anglicisms}

English terms used in Spanish can be regarded as anglicisms. They may be orthographically or phonetically adapted to Spanish, but in any case, they are English loanwords used in Spanish. The penetration of anglicisms in various fields has been extensively examined by several authors in Spain. For example, the following fields have been explored: beauty and fashion (Luján-García 2017; Tejedor Martínez 2017); sports (Rodríguez González 2012; Rodríguez Medina 2016); TV commercials (García-Morales et al. 2016); marketing (López Zurita 2018); toys and games (Luján-García 2015); even areas such as drugs (Rodríguez González 1994) and sex (Crespo-Fernández and Luján-García 2017, 2018). All these authors have reported that there is a remarkable number of anglicisms in Spanish, and that they are used with different functions. In some cases, these aim at looking cool and fashionable, while in others anglicisms are used simply because there is no Spanish equivalent term or the English term is shorter to express a specific concept. One more reason to use anglicisms is linked with axiological values such as the wish to use euphemistic terms, since the Spanish term may be taboo or politically incorrect, especially in particular areas such as sex and drugs.

The English language plays a prominent role in international professions. Alcaraz Varó (2000) highlighted the importance of vocabulary and lexis in specialized technical and/ or semi-technical areas. The author used the terms meta-language or technolect to refer to the particular type of terms used by professionals in their areas of specialty (law, medicine, engineering). The terminology or technical vocabulary is composed of terms whose meanings need to be well-defined, with an unequivocal significance to avoid ambiguity. These terms could be considered monosemic, as they have a defined meaning understood by any professional working in a particular professional field.

When dealing with scientific or technical vocabulary, English is the most extended language worldwide (Brock-Utne 2016; Feez and Quinn 2017; Pennycook 2017). Being present in almost any qualified domain, this international language occupies a dominant position. Alcaraz Varó $(2000,62)$ claims that English has certain features that contribute to the development of qualities that are essential for the language of science and technology: expressive accuracy, objectivity and approximate exposition.

The reasons set out above explain why English terms are so common in areas such as engineering and IT. Technical terms such as upgrade, download or clone are employed by expert users as anglicisms in their native languages. Therefore, expressions like voy a hacer un clone/clon ('I'm going to do a clone') or voy a clonar este repositorio ('I'm going to clone this repository') are not unusual for a Spanish speaking professional in these fields. The knowledge and use of technical anglicisms by a sample of students in the professional field of Telecommunications Engineering and in the context of the MACbioIDi glossary will also be explored in this article. 


\section{Methodology}

\subsection{Classification of Anglicisms}

In order to categorize the sample of anglicisms collected, the most recent and extended categorization was chosen (Pulcini, Furiassi, and Rodríguez González 2012, 6). This classification (Figure 2) distinguishes, grosso modo, direct and indirect loanwords. Within the section of direct loanwords, different types may be broken down: hybrids, false loanwords also called pseudo-anglicisms - and loanwords per se, which may be adapted or non-adapted. These loanwords are essentially lexical. On the right side of Figure 2 the indirect loanwords can be observed, within which calques and semantic loanwords can be discerned. Under the heading of calques, three types may be distinguished, loan translations, loan renditions and loan creations. The indirect loans are syntactic and affect the structure of the sentence, while the lexical ones address the recipient language. In this study, the focus has been on the direct lexical borrowings. This categorization was helpful to classify the number of lexical items that have been compiled in our corpus.

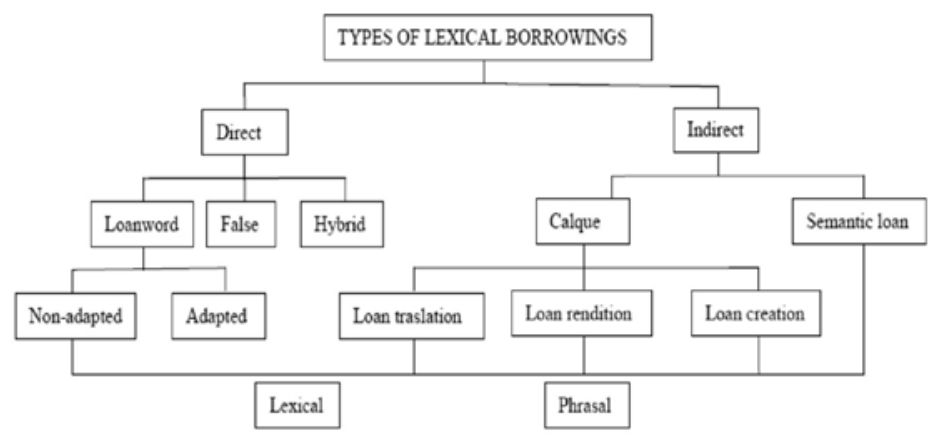

FIgure 2. Classification of anglicisms by Pulcini, Furiassi and Rodríguez González $(2012$, 6).

\subsection{Sample}

This reflective qualitative methodological approach was undertaken with six postgraduate students of a master's degree in Telecommunications Engineering during the academic year 2018-2019, whose language level was between B1+ and B2 of the Common European Framework of Reference for Languages. These learners worked as a team with the intention of producing, reflecting on, and managing accurate knowledge in their field (Telecommunications and ICT) by means of the MACbioIDi bilingual glossary. The project was designed by two ESP professors of the subject English for Telecommunications Engineering (ETE), who acted as observers and listeners of students' comments regarding each term, and as readers and examiners of students' additions to the glossary.

This collaborative work also required the identification of ESP terms, the creation of adequate definitions, which were not copied and pasted from monolingual dictionaries, and their correct pronunciations. Moreover, self-regulating reflections dealing with the Spanish terms and, consequently, the possible use of anglicisms, were added by the participants. An active ESP vocabulary was the target orienting this research. 
Although the main aim of this analysis was to reflect on the ESP vocabulary extracted from the MACbioIDi project, the participants performed an active role in the creation of the glossary with written and spoken comments about each term (definitions, grammatical function, etc.). Thus, the results presented in the following sections show the work produced by students in its original version, without any alterations or corrections by the instructors.

\subsection{Instruments: The Bilingual Team Glossary and the Abstracts}

The aim was to test and describe how the vocabulary was collected and added to a collaborative document by students. This included a bilingual team glossary that was shared and edited as a Google Excel document during the course.

This MACbioIDi glossary was initially designed by the instructors as a collaborative task with the lexis extracted from the formative wiki of the MACbioIDi project (Figure 1 ), whose main influential field was telecommunications engineering. The terms were classified in seven subtopics: GitHub, Building 3D Slicer, Python, PythonNumpy; Matplotlib; QT framework and VTK.

During the productive team phase, students completed the document by adding the grammatical function of the word (noun, verb, etc.), its elaborate definition (which they did not copy and paste from a dictionary), its pronunciation in English, and the Spanish term and its adaptation if the term did not have a reference in Spanish yet. The data collected also provided feedback on students' knowledge and use of the selected ESP vocabulary. Additionally, the use of the selected terms in their professional field also indicated whether the learners used a Spanish word or an English adaptation, as in the case of usar un branch ('use a branch').

The collaborative glossary was thus the main instrument of analysis in this study. Another instrument was the English abstract that each student produced based on their final master's thesis project.

The data collected addresses each research question. Firstly, formal/informal learning settings were considered together with the adequate use and knowledge students had of the list of terms added in the glossary. Secondly, learners were interviewed on how they would use each English term in their professional Spanish context, so that researchers could identify any anglicisms. Finally, the abstracts were analyzed to compare learners' accuracy and use of professional terms. The glossary was completed during the first weeks of the semester, while the abstracts were produced by the end of the semester (2018-2019).

\section{Results and Discussion}

This section is dedicated to presenting the learning achievements according to the conceptual approach of lifelong learning ecologies for ESP and professional English. The results address the three questions posed in this research. 


\subsection{Research Question 1}

$R Q 1$. What collaborative and reflective dimensions have been implemented to elaborate the MACbioIDi glossary with the expressions known andlor used by ESP students?

In order to respond to the first research question, the focus was on the MACbioIDi glossary and the seven topics addressing the specific vocabulary extracted from its formative wiki, shown in the Tables 3-9 below with a total of 96 English expressions. The glossary and entries were accurately classified by students and resulted in a predominant number of nouns (73 in total) over verbs (20). There was also one adjective, one adverbial expression (randomly, Table 7 , topic 5) and one abbreviation (IDE, Table 4). The writing of the glossary is an instance of informal learning, and in this particular case, it was set in a ubiquitous learning environment with in-class comments and reflections and out-of-class additions.

From a comparative perspective, the seven subtopics were similar regarding learners' reflective analysis. Students collaboratively reported that they knew most of the terms but did not use them frequently, as it can be seen in Tables 3-9. Considering the seven subtopics extracted from the MACbioIDi formative wiki, the two content areas that the students used more frequently in their academic and professional fields were 3D Slicer and GitHub, in this order.

Generally, the definitions students created for each term and under each subtopic followed the expected structure and, in most cases, corresponded with the grammatical function of the term. Clone was an example of a definition that was explained by learners both as a noun and a verb (Figure 3). It is noteworthy that the students used adequate and precise structures that were also contextualized in professional ESP.

Most definitions used the structure of the concept followed by the verb (e.g., is, refers to, ...) and the complements. Some definitions were expanded with another sentence to complete the explanation. In some cases, to-markers were introduced at the beginning of definitions, for instance, for the entries download, update, upgrade and sign in (Table 4).

The word class of the terms (noun, verb, adjective...) was added only for the entries in the first topic $($ GitHub) and not for the ones in the remaining six subtopics. The definitions were analyzed to check the correspondence between the definitions and grammatical functions. This correspondence was perfect: the students recognized the word classes of all 96 expressions. This task is often practiced in the English for Telecommunications Engineering classroom with a variety of techniques for eliciting English. Its aim is to teach students to identify and locate various expressions in a text and become aware of their collocates.

Regarding pronunciation, participants actively dedicated a column to reflect upon the pronunciation of each term in English, considering not only how the terms were pronounced but also the stress of each word. Since they were MA students in Telecommunications Engineering and had not studied the phonetics and phonology of English, they were not asked to transcribe the terms phonetically but rather to use their own respelling of the word with the stressed syllable in capital letters, which is another common strategy in the ETE classroom. Moreover, students were also used to accessing a monolingual dictionary (e.g., Cambridge Online Dictionary) to listen to the pronunciation of new terms. 
- A branch is a parallel version of a repository. It is contained within the repository, but does not affect the primary or master branch allowing you to work freely without disrupting the "live" version. When you've made the changes you want to make, you can merge your branch back into the master branch to publish your changes.

- A clone is a copy of a repository that lives on your computer instead of on a website's server somewhere, or the act of making that copy. You can push your local changes to the remote to keep them synced when you're online.

- A commit, or "revision", is an individual change to a file (or set of files). It's like when you save a file, except with Git, every time you save it, it creates a unique ID (a.k.a. the "SHA" or "hash") that allows you to keep record of what changes were made when and by whom. Commits usually contain a commit message which is a brief description of what changes were made.

- A diff is the difference in changes between two commits, or saved changes. The diff will visually describe what was added or removed from a file since its last commit.

- Fetching refers to getting the latest changes from an online repository without merging them in. Once these changes are fetched you can compare them to your local branches.

Figure 3. Examples of students' definitions.

Another significant observation is the use of some terms which were added to the glossary as headwords but were then also used as part of the definitions of other terms. Two examples extracted from the Subtopic 1 (GitHub) are the expressions branch and clone: branch was the first word used in the glossary, and it was also integrated in the definitions for the terms fetch and merge; and clone was used a key term for the GitHub glossary (as a verb and a noun) and as a noun that was part of the definition for the term remote in the same subtopic (see Figure 3). Two expressions frequently used in definitions were software (in 13 definitions) and file (in eight other glossary terms) which are in widespread use in ICT. Some other examples of key terms in the MACbioIDi glossary and of terms being repeated as part of a definition for another key term can be found in Table 1 .

TABLE 1. ESP key terms from MACbioIDi reused in definitions.

\begin{tabular}{|l|l|}
\hline Key Terms & Key Terms within Definitions \\
\hline Branch & fetch; merge \\
\hline Clone & remote \\
\hline Commit & diff; push \\
\hline Git & commit; merge; push; remote; repository; SSH keys \\
\hline Merge & branch \\
\hline Pull & fork; merge \\
\hline Push & clone; click \\
\hline Remote & clone; pull; push \\
\hline Repository & branch; clone; fetch; fork: merge; pull requests; push \\
\hline Open source & git \\
\hline Environment & setup; framework; user \\
\hline Build & CMake \\
\hline Libraries & framework; IDE \\
\hline Remote & clone; pull; push \\
\hline Repository & branch; clone; fetch; fork: merge; pull requests; push \\
\hline
\end{tabular}




\begin{tabular}{|l|l|}
\hline Open source & Git \\
\hline Environment & setup; framework; user \\
\hline Build & CMake \\
\hline Libraries & framework; IDE \\
\hline Password & SSH keys \\
\hline Framework & IDE \\
\hline User & fork; git; pull request; setting; backend; user guide \\
\hline Run & multi-platform; threading/multi-threading \\
\hline Package & tool-kit \\
\hline Command & merge; script; pipeline \\
\hline Hardware & software; interface \\
\hline Software & open source; environment; build; loop; plug-ins; libraries; framework; \\
& IDE; multi-platform; tool-bar; frontend; backend; driver \\
\hline Interface & git; merge \\
\hline Update & fork \\
\hline Sign in & log in \\
\hline Folder & repository \\
\hline File & commit; diff; git; markdown; pull; repository; folder; checkout \\
\hline Script & commit \\
\hline Master & branch; slave \\
\hline Block & flow; input; output \\
\hline Flow & master; switch \\
\hline Input & output; feedback; pipeline; binding; mapper \\
\hline Set & commit; build; framework; script; byte; mapper \\
\hline Array & String \\
\hline Setting & Default \\
\hline
\end{tabular}

This aspect also included a formal/informal reflective analysis, since learners revealed their knowledge, experience and use of the terms proposed, together with the correct pronunciations. This formal/informal collaborative analysis offered students some individual and team reflections about their learning.

\subsection{Research Question 2}

RQ2. From the learners' reflective perspective, what professional English terms, considered anglicisms, have been adapted in the Spanish language according to the seven subtopics of the MACbioIDi glossary?

The use of the Spanish term or its Spanish adaptation (anglicism) in a professional context was also considered by the participants of this study. A total of 42 anglicisms were acknowledged according to the seven subtopics extracted from the MACbioIDi wiki (GitHub, 3D Slicer, ...), as shown in Table 2 .

The most common type of anglicisms found in the corpus were the non-adapted ones, i.e. English lexical items that have not undergone any kind of adaptation to the recipient language. For example, terms such as branch, password and user are used in Spanish in their original forms. The second kind of anglicisms that were relatively frequently used were hybrids, i.e., the combination of two or more lexical items in which one term is English and the other Spanish. For example, hacer un commit ('to create a commit'). There were also one calque (interfaz for 'interface') and some derivational hybrids such as plotear (from 'plotting') and mapear (from 'mapping'), as shown in Tables 3-9. 
TABLE 2. The number and types of anglicisms per topic.

\begin{tabular}{|l|l|l|}
\hline $\begin{array}{l}\text { MACbioIDi } \\
\text { Glossary Topic }\end{array}$ & $\begin{array}{l}\text { No. of Anglicisms } \\
\text { (Students' Reflections) }\end{array}$ & $\begin{array}{l}\text { Most Common Types of } \\
\text { Anglicisms }\end{array}$ \\
\hline GitHub & 6 & Hybrid \\
\hline 3D Slicer & 18 & Non-adapted + Hybrid \\
\hline Python & 3 & Non-adapted + Hybrid \\
\hline PythonNumpy & 1 & Non-adapted \\
\hline Matplotlib & 6 & Non-adapted + Hybrid \\
\hline QT framework & 5 & Non-adapted \\
\hline VTK & 4 & Non-adapted + Hybrid \\
\hline
\end{tabular}

The following sections deal with the examination of vocabulary and anglicisms for each of the seven topics of the MACbioIDi glossary.

\subsubsection{Building GitHub Vocabulary}

GitHub, ${ }^{2}$ a development platform created for developers to review code and manage and develop software, was the first subtopic in the MACbioIDi glossary. It included professional vocabulary and learner-added grammatical function of 15 GitHub terms (ten nouns, five verbs, one adjective and one acronym), as can be seen in Table 3.

Students marked three words in the first column (Git, Remote and Repository) as unnecessary for this ESP glossary: the first term is a brand, the second common in different fields, and the third one also too generic. No terms were removed from the other six subtopics (see Tables 4-9). In the subtopic GitHub, the information on word class was added, and the definition of clone expanded to include the explanation for the verb (Table 3).

TABLE 3. MACbioIDi glossary: students' work for the subtopic GitHub.

\begin{tabular}{|l|l|l|l|l|}
\hline $\begin{array}{l}\text { English } \\
\text { Term (Cat- } \\
\text { egory) }\end{array}$ & Definition & Pron. & \multicolumn{2}{|l|}{$\begin{array}{l}\text { Spanish (Translation/ } \\
\text { Adaptation) }\end{array}$} \\
Branch (n) & $\begin{array}{l}\text { A branch is a parallel version of a repository. It is } \\
\text { contained within the repository, but does not affect } \\
\text { the primary or master branch allowing you to work } \\
\text { freely without disrupting the “live" version. When } \\
\text { you've made the changes you want to make, you } \\
\text { can merge your branch back into the master branch } \\
\text { to publish your changes. }\end{array}$ & BRANCH & rama & $\begin{array}{l}\text { Usar un } \\
\text { branch }\end{array}$ \\
\hline Clone (v) & $\begin{array}{l}\text { A clone is a copy of a repository that lives on your } \\
\text { computer instead of on a websites server some- } \\
\text { where, or the act of making that copy. You can } \\
\text { push your local changes to the remote to keep them } \\
\text { synced when youre online. }\end{array}$ & KLON & clonar & $\begin{array}{l}\text { Hacer un } \\
\text { clon }\end{array}$ \\
\hline
\end{tabular}

2 The GitHub platform can be accessed here: https://github.com. 


\begin{tabular}{|c|c|c|c|c|}
\hline $\begin{array}{l}\text { Commit } \\
\text { (n) }\end{array}$ & $\begin{array}{l}\text { A commit, or "revision", is an individual change to } \\
\text { a file (or set of files). It's like when you save a file, } \\
\text { except with Git, every time you save it creates a } \\
\text { unique ID (a.k.a. the "SHA" or "hash") that allows } \\
\text { you to keep record of what changes were made } \\
\text { when and by whom. Commits usually contain a } \\
\text { commit message which is a brief description of } \\
\text { what changes were made. }\end{array}$ & ko-MIT & comisión & $\begin{array}{l}\text { Hacer un } \\
\text { comit }\end{array}$ \\
\hline $\operatorname{Diff}(n)$ & $\begin{array}{l}\text { A diff is the difference in changes between two } \\
\text { commits, or saved changes. The diff will visually } \\
\text { describe what was added or removed from a file } \\
\text { since its last commit. }\end{array}$ & DIF & \multicolumn{2}{|c|}{$\begin{array}{l}\text { diferencia / Mirar la dife- } \\
\text { rencia }\end{array}$} \\
\hline Fetch (v) & $\begin{array}{l}\text { Fetching refers to getting the latest changes from an } \\
\text { online repository without merging them in. Once } \\
\text { these changes are fetched you can compare them to } \\
\text { your local branches. }\end{array}$ & FECH & traer & $\begin{array}{l}\text { Hacer un } \\
\text { fetch }\end{array}$ \\
\hline Fork (n) & $\begin{array}{l}\text { A fork is a personal copy of another user's reposi- } \\
\text { tory that lives on your account. Forks allow you to } \\
\text { freely make changes to a project without affecting } \\
\text { the original. Forks remain attached to the original, } \\
\text { allowing you to submit a pull request to the origi- } \\
\text { nal's author to update with your changes. You can } \\
\text { also keep your fork up to date by pulling in updates } \\
\text { from the original. }\end{array}$ & FORK & bifurcar & $\begin{array}{l}\text { Hacer un } \\
\text { fork }\end{array}$ \\
\hline Git (n) & $\begin{array}{l}\text { Git is an open source program for tracking changes } \\
\text { in text files. It was written by the author of the } \\
\text { Linux operating system, and is the core technology } \\
\text { that GitHub, the social and user interface, is built } \\
\text { on top of. }\end{array}$ & GIT & repositorio & $\begin{array}{l}\text { Hacer / Tener } \\
\text { un Git }\end{array}$ \\
\hline $\begin{array}{l}\text { Markdown } \\
\text { (n) }\end{array}$ & $\begin{array}{l}\text { Markdown is a simple semantic file format, not } \\
\text { too dissimilar from .doc, .rtf and .txt. Markdown } \\
\text { makes it easy for even those without a web-pub- } \\
\text { lishing background to write prose (including with } \\
\text { links, lists, bullets, etc.) and have it displayed like a } \\
\text { website. }\end{array}$ & $\begin{array}{l}\text { MARK- } \\
\text { DAUN }\end{array}$ & \multicolumn{2}{|c|}{ formato Markdown } \\
\hline Merge (v) & $\begin{array}{l}\text { Merging takes the changes from one branch (in } \\
\text { the same repository or from a fork), and applies } \\
\text { them into another. This often happens as a pull } \\
\text { request (which can be thought of as a request to } \\
\text { merge), or via the command line. A merge can } \\
\text { be done automatically via a pull request via the } \\
\text { GitHub web interface if there are no conflicting } \\
\text { changes, or can always be done via the com- } \\
\text { mand line. }\end{array}$ & MERSH & \multicolumn{2}{|c|}{ mezclar / fuse / Combine } \\
\hline Pull (v) & $\begin{array}{l}\text { Pull refers to when you are fetching in changes and } \\
\text { merging them. For instance, if someone has edited } \\
\text { the remote file you're both working on, you'll want } \\
\text { to pull in those changes to your local copy so that } \\
\text { it's up to date. }\end{array}$ & PUL & \multicolumn{2}{|c|}{ traer (más cerca) } \\
\hline
\end{tabular}




\begin{tabular}{|c|c|c|c|}
\hline $\begin{array}{l}\text { Pull request } \\
(\mathrm{n})\end{array}$ & $\begin{array}{l}\text { Pull requests are proposed changes to a repository } \\
\text { submitted by a user and accepted or rejected by a } \\
\text { repository's collaborators. }\end{array}$ & $\begin{array}{l}\text { PUL ri- } \\
\text { KUEST }\end{array}$ & $\begin{array}{l}\text { propuesta / petición para } \\
\text { traer }\end{array}$ \\
\hline Push (v) & $\begin{array}{l}\text { Pushing refers to sending your committed changes } \\
\text { to a remote repository, such as a repository hosted } \\
\text { on GitHub. For instance, if you change something } \\
\text { locally, you'd want to then push those changes so } \\
\text { that others may access them. }\end{array}$ & PUSH & cargar (upload) \\
\hline $\begin{array}{l}\text { Remote } \\
\text { (adj) }\end{array}$ & $\begin{array}{l}\text { This is the version of something that is hosted on a } \\
\text { server, most likely GitHub. It can be connected to } \\
\text { local clones so that changes can be synced. }\end{array}$ & ri-MOUT & remoto \\
\hline $\begin{array}{l}\text { Repository } \\
(\mathbf{n})\end{array}$ & $\begin{array}{l}\text { A repository is the most basic element of GitHub. } \\
\text { They're easiest to imagine as a project's folder. A } \\
\text { repository contains all of the project files (including } \\
\text { documentation), and stores each file's revision his- } \\
\text { tory. Repositories can have multiple collaborators } \\
\text { and can be either public or private. }\end{array}$ & $\begin{array}{l}\text { ri-PO-see- } \\
\text { to-ry }\end{array}$ & repositorio \\
\hline SSH Key & $\begin{array}{l}\text { SSH keys are a way to identify yourself to an online } \\
\text { server, using an encrypted message. It's as if your } \\
\text { computer has its own unique password to another } \\
\text { service. GitHub uses SSH keys to securely transfer } \\
\text { information to your computer. }\end{array}$ & $\begin{array}{l}\text { ES-ES- } \\
\text { EISCH KII }\end{array}$ & $\begin{array}{l}\text { SSH (always used as ab- } \\
\text { brev. not as long term) }\end{array}$ \\
\hline
\end{tabular}

Regarding the bilingual adaptation of the 15 terms, the students compared the Spanish expression for each concept and the English adaptation of the six expressions they used with the English term as in hacer un clon or usar un branch. Some English nouns such as branch, commit, fork and git have become verbs in Spanish. The terms clone and commit have also been orthographically adapted to Spanish: clon (the final -e is dropped) and comit (the - $\mathrm{m}$ is not doubled). These can be considered hybrid anglicized expressions. The anglicisms identified by students have been highlighted in the right-hand column of Tables 3-9. Readers of this article are reminded that this is the original work done by students without any corrections or modifications made by the instructors.

\subsubsection{Building 3D Slicer Vocabulary}

$3 D$ Slicer $^{3}$ is another worldwide open source platform for developers, created by Harvard University, for medical image computing and processing and $3 \mathrm{D}$ visualization. It was the second subtopic in the collaborative MACbioIDi glossary with 29 nouns and 11 verbs as shown in Table 4. Feedback was provided, and, for example, it was suggested that the students use the infinitival marker (Table 4, see the cases in bold). Moreover, the missing information on the pronunciation of examine was elicited by the teacher in class. 
TABLE 4. MACbioIDi glossary: students' work for the subtopic 3D Slicer.

\begin{tabular}{|c|c|c|c|c|}
\hline $\begin{array}{l}\text { English Term } \\
\text { (Category) }\end{array}$ & Definition & Pron. & \multicolumn{2}{|c|}{$\begin{array}{l}\text { Spanish (Translation/ } \\
\text { Adaptation) }\end{array}$} \\
\hline $\begin{array}{l}\text { Open Source } \\
\text { (n) }\end{array}$ & $\begin{array}{l}\text { Software that is open source allows developers } \\
\text { to see and modify the source code (like Firefox } \\
\text { does!) }\end{array}$ & O-pen SORS & $\begin{array}{l}\text { Código } \\
\text { abierto }\end{array}$ & open source \\
\hline $\begin{array}{l}\text { Environment } \\
\text { (n) }\end{array}$ & $\begin{array}{l}\text { All the software, complements and directory } \\
\text { structure that a programmer can have to do his } \\
\text { job }\end{array}$ & $\begin{array}{l}\text { en-VAI-ron- } \\
\text { ment }\end{array}$ & \multicolumn{2}{|l|}{ Entorno } \\
\hline Build (v) & $\begin{array}{l}\text { Assemble separate pieces of software in a set of } \\
\text { "tangible" (often executable) results }\end{array}$ & BILD & \multicolumn{2}{|c|}{ hacer un build } \\
\hline Cmake (n) & $\begin{array}{l}\text { CMake is a build process manager independent } \\
\text { from a compiler (not a complier itself!) }\end{array}$ & SEE-MEIK & \multicolumn{2}{|l|}{ Cmake } \\
\hline Loop (n) & $\begin{array}{l}\text { In software, a loop is something that repeats } \\
\text { itself several times (indefinitely or until a condi- } \\
\text { tion is met) }\end{array}$ & LUP & \multicolumn{2}{|c|}{ Bucle / lazo cerrado } \\
\hline Plugins (n) & $\begin{array}{l}\text { An installable addition to existing executable } \\
\text { software }\end{array}$ & PLOG-in & \multicolumn{2}{|c|}{$\begin{array}{l}\text { plugins / plug-ins / plu- } \\
\text { guin }\end{array}$} \\
\hline Libraries (n) & $\begin{array}{l}\text { Collections of complementary software used to } \\
\text { perform certain tasks more easily }\end{array}$ & LAI-bra-ris & \multicolumn{2}{|c|}{$\begin{array}{l}\text { bibliotecas (sometimes } \\
\text { mistakenly used as } \\
\text { "librerías") }\end{array}$} \\
\hline Setup (n) & $\begin{array}{l}\text { The process of installing a computer program or } \\
\text { environment }\end{array}$ & SET-ap & \multicolumn{2}{|l|}{ instalación } \\
\hline Password (n) & $\begin{array}{l}\text { A secret word that you specify to assure others } \\
\text { (or a service) that you are who you claim to be }\end{array}$ & PASS-word & password & contraseña \\
\hline Framework (n) & $\begin{array}{l}\text { A collection of libraries that set a software devel- } \\
\text { opment environment }\end{array}$ & $\begin{array}{l}\text { FREIM- } \\
\text { work }\end{array}$ & \multicolumn{2}{|l|}{ framework } \\
\hline $\begin{array}{l}\text { IDE, Inte- } \\
\text { grated De- } \\
\text { velopment } \\
\text { Environment } \\
\text { (n phrase) }\end{array}$ & $\begin{array}{l}\text { A collection of frameworks and libraries bun- } \\
\text { dled in a stand-alone piece of software }\end{array}$ & AI-DI-I & $\begin{array}{l}\text { IDE, en- } \\
\text { torno de } \\
\text { desarrollo } \\
\text { integrado }\end{array}$ & $\begin{array}{l}\text { Pron. / } \\
I D E \text { \& } \\
I D E /\end{array}$ \\
\hline User (n) & $\begin{array}{l}\text { An abstraction (also often an isolated environ- } \\
\text { ment) for a person or agent }\end{array}$ & U-ser & $\begin{array}{l}\text { YUSER / } \\
\text { USER }\end{array}$ & usuario \\
\hline Run (n) & Execute a program & RAN & \multicolumn{2}{|c|}{ ejecutar/correr/lanzar } \\
\hline $\begin{array}{l}\text { Multi-plat- } \\
\text { form }(\mathrm{n})\end{array}$ & $\begin{array}{l}\text { A software that is able to run on different oper- } \\
\text { ating systems }\end{array}$ & $\begin{array}{l}\text { MUL-ti } \\
\text { PLAT-form }\end{array}$ & $\begin{array}{l}\text { multiplata- } \\
\text { forma }\end{array}$ & \begin{tabular}{|l|} 
Also \\
(ENGL \\
Crossplat- \\
form) \\
\end{tabular} \\
\hline Tool (n) & Something made to perform a task & TUUL & herramienta & $\begin{array}{l}\text { Pron. Ilas / } \\
\text { tuls/ }\end{array}$ \\
\hline Tool-bar (n) & $\begin{array}{l}\text { A graphical way (bar) to show available tools on } \\
\text { a software }\end{array}$ & TUUL-bar & $\begin{array}{l}\text { barra de } \\
\text { herramien- }\end{array}$ & $\begin{array}{l}\text { Pron. /Tul } \\
\text { BAR/ }\end{array}$ \\
\hline
\end{tabular}




\begin{tabular}{|c|c|c|c|}
\hline Package (n) & $\begin{array}{l}\text { A closed directory whose contents you can use } \\
\text { (but not modify) }\end{array}$ & PAK-isch & paquete \\
\hline Command $(\mathrm{n})$ & $\begin{array}{l}\text { Order you can give a computer from a terminal } \\
\text { prompt }\end{array}$ & ko-MAND & comando \\
\hline Tool-kit (n) & A package of tools & TUUL-kit & $\begin{array}{l}\text { tool-kit / set de her- } \\
\text { ramientas / paquete de } \\
\text { herramientas }\end{array}$ \\
\hline Hardware (n) & $\begin{array}{l}\text { Tangible piece of assembled electronics that can } \\
\text { perform a certain task }\end{array}$ & HARD-wer & hardware \\
\hline Software (n) & $\begin{array}{l}\text { A intangible piece of executable electrical infor- } \\
\text { mation stored in hardware memory that makes } \\
\text { it perform a task }\end{array}$ & Soft-wer & software \\
\hline Interface (n) & $\begin{array}{l}\text { An intermediate piece of software/hardware that } \\
\text { eases communication between componentes }\end{array}$ & IN-ter-feis & interfaz \\
\hline Download (v) & $\begin{array}{l}\text { To acquire data or software via the internet or } \\
\text { other network }\end{array}$ & DAUN-loud & bajar, descargar \\
\hline Upload (v) & $\begin{array}{l}\text { To put data or software on a internet or net- } \\
\text { work location }\end{array}$ & AP-loud & subir, cargar \\
\hline Update (v) & $\begin{array}{l}\text { To slightly modify a software to a more recent } \\
\text { version (or announcing the possibility) }\end{array}$ & AP-deit & actualización \\
\hline Upgrade (v) & $\begin{array}{l}\text { To modify a piece of soft/hard-ware to a more } \\
\text { recent version }\end{array}$ & AP-greid & mejora \\
\hline $\begin{array}{l}\text { Registration } \\
\text { (n) }\end{array}$ & The act of storing your presence somwhere & $\begin{array}{l}\text { RE-yis- } \\
\text { TREI-shon }\end{array}$ & registrarse \\
\hline Sign up (v) & To register with credentials in certain service & SAIN AP & $\begin{array}{l}\text { registrarse de la } \\
\text { aplicación }\end{array}$ \\
\hline Sign in $(\mathrm{v})$ & $\begin{array}{l}\text { To use your previously stored credentials to ac- } \\
\text { cess or use a service }\end{array}$ & SAIN IN & entrar en la aplicación \\
\hline Folder (n) & $\begin{array}{l}\text { An abstraction representing a collection of files } \\
\text { and other folders (also directory) }\end{array}$ & FOL-der & directorio, carpeta \\
\hline File $(\mathrm{n})$ & A self-contained piece of information & FAIL & archivo, fichero \\
\hline Checkout (v) & To examine & $\begin{array}{l}\text { TO BE } \\
\text { DONE BY } \\
\text { SS! } \\
\end{array}$ & checkout \\
\hline Path (n) & $\begin{array}{l}\text { The way to get to a certain directory or file } \\
\text { beginning from a particular root }\end{array}$ & $\mathrm{PAZH}$ & ruta \\
\hline Click (v) & $\begin{array}{l}\text { pushing the mouse's buttons to trigger some } \\
\text { action }\end{array}$ & KLIK & hacer click \\
\hline Script (n) & a structured set of sequential commands & SKRIPT & script \\
\hline
\end{tabular}




\begin{tabular}{|l|l|l|l|}
\hline $\begin{array}{l}\text { Search engine } \\
\text { (n) }\end{array}$ & $\begin{array}{l}\text { software that allows you to apply filters to find } \\
\text { what you want in a large collection of entries }\end{array}$ & $\begin{array}{l}\text { SERCH EN- } \\
\text { yin }\end{array}$ & buscador \\
\hline Master (n) & $\begin{array}{l}\text { A piece of soft/hard-ware that "controls" the } \\
\text { workflow of other pieces }\end{array}$ & MAS-ter & maestro \\
\hline Slave (n) & $\begin{array}{l}\text { A piece of soft/hard-ware that is “controlled" by } \\
\text { a master }\end{array}$ & SLEIV & esclavo \\
\hline Database (n) & $\begin{array}{l}\text { A structure in which you can store data and } \\
\text { stablish relations between data items }\end{array}$ & DEI-ta-beis & base de datos \\
\hline Login (v) & Same as sign in & LOG-in & login \\
\hline
\end{tabular}

Regarding the bilingual adaptation, and the influence of English, especially in the field of ICT and Telecommunications, the results reveal that some of these technical terms such as CMake, plugins/plug-ins/pluguin/plujin, framework, hardware, software, checkout, script, login are used in their pure or non-adapted English forms and no Spanish equivalent term seems to be used (also in Table 4). Other anglicisms seem to co-exist with their Spanish equivalents. This is the case for password, which is used along with contrasena; tool-kit which co-exists with set de herramientas ('tool set') and paquete de herramientas. ('tool pack'). There are also some cases in which the English noun becomes a verb by using the Spanish verb hacer ('do', 'make') in hybrid expressions such as: hacer un build ('to do a build') and hacer click (lit. 'to make a click').

\subsubsection{Building Python Vocabulary}

The third subtopic was dedicated to Python and it comprised a total of 16 expressions (14 nouns and two verbs), see Table 5. Python is a software programming language for developers that is used worldwide. ${ }^{4}$

TABle 5. MACbioIDi Glossary: Students' work for the subtopic Python.

\begin{tabular}{|l|l|l|l|}
\hline $\begin{array}{l}\text { English Term } \\
\text { (Category) }\end{array}$ & Definition & Pron. & $\begin{array}{l}\text { Spanish (Translation/ } \\
\text { Adaptation) }\end{array}$ \\
\hline Block (n) & A delimited region of code & BLOK & bloque \\
\hline Flow (n) & $\begin{array}{l}\text { The way of controlling how a line of block of } \\
\text { code jumps to another }\end{array}$ & FLOU & flujo \\
\hline Input (n) & $\begin{array}{l}\text { Information that an agent has to enter to a } \\
\text { function/block }\end{array}$ & IN-put & entrada \\
\hline Output (n) & $\begin{array}{l}\text { The reult of a function/block processing } \\
\text { something (often an input) }\end{array}$ & AUT-put & salida \\
\hline $\begin{array}{l}\text { Programming } \\
\text { (n) }\end{array}$ & $\begin{array}{l}\text { To write software in text format and using some } \\
\text { language }\end{array}$ & $\begin{array}{l}\text { PRO-gra- } \\
\text { ming }\end{array}$ & programar \\
\hline Scope (n) & The code region in which uniform rules apply & SCOUP & ámbito, alcance? \\
\hline Byte (n) & A set of 8 1-or-0 values & BAIT & byte \\
\hline
\end{tabular}

4 The Python website is accessible here: https://www.python.org 


\begin{tabular}{|l|l|l|l|}
\hline Set $(\mathrm{n})$ & A defined group of data & SET & conjunto, poner ? \\
\hline Bitarray $(\mathrm{n})$ & A linear group or ordered list of 1-or-0 values & bit-a-RAY & vector de bits \\
\hline Array $(\mathrm{n})$ & An ordered list of items & a-RAY & vector \\
\hline Delete $(\mathrm{v})$ & To make disappear, cleanup & de-LEIT & borrar / hacer delete \\
\hline Default (n) & $\begin{array}{l}\text { A value that applies if not modified manually by } \\
\text { some setting }\end{array}$ & di-FAULT & por defecto \\
\hline Range (n) & Distance between two extremes & REINSCH & rango \\
\hline String (n) & $\begin{array}{l}\text { A consecutive list of characters (an array of } \\
\text { characters) }\end{array}$ & STRING & cadena / cuerda \\
\hline Runtime (n) & Period of program execution & RAN-taim & tiempo de ejecución \\
\hline Downtime (n) & Period of unavailability & DAUN-time & tiempo de parada \\
\hline
\end{tabular}

Regarding the bilingual adaptation, we can observe that vector de bits, for example, is used in Spanish for the English bitarray. In addition, the Spanish verb borrar seems to co-exist with the hybrid expression hacer delete (lit. 'do a delete'), which combines the Spanish verb hacer and the English verb delete.

All the tables in the Results section show the students' work. In the case of Table 5, there are some question marks added by students in the fourth column since they were not sure about the Spanish use of the term. The table also highlights the anglicisms that the students identified in this subtopic (byte, vector de bits, hacer delete).

\subsubsection{Building PythonNumpy Vocabulary}

PythonNumpy, also NumPy, is a package used with Python for technical computing with a variety of functions and tools. Only three terms were classified for the PythonNumpy vocabulary, all of them nouns (Table 6).

TABLE 6. MACbioIDi Glossary: Students' work for the subtopic PythonNumpy.

\begin{tabular}{|l|l|l|l|}
\hline $\begin{array}{l}\text { English Term } \\
\text { (Category) }\end{array}$ & Definition & Pron. & $\begin{array}{l}\text { Spanish (Translation/ } \\
\text { Adaptation) }\end{array}$ \\
\hline $\begin{array}{l}\text { Threading /multi- } \\
\text { threading (n/v) }\end{array}$ & $\begin{array}{l}\text { A way to make code run in parallel (not } \\
\text { sequentially) }\end{array}$ & $\begin{array}{l}\text { M U L - t i } \\
\text { ZRE-ding }\end{array}$ & hilo / multihilo \\
\hline Setting (n) & $\begin{array}{l}\text { A collection of parameters a user } \\
\text { adjusted to its preferences }\end{array}$ & SE-ting & configuración \\
\hline Bug (n) & $\begin{array}{l}\text { An unexpected (often unwanted) } \\
\text { program behavior }\end{array}$ & BUG & bug / error \\
\hline
\end{tabular}

Regarding the bilingual adaptation in this short list, it can be observed that the Spanish term error co-exists with the English equivalent bug.

More information on the NumPy website at http://www.numpy.org. 


\subsubsection{Building Matplotlib Vocabulary}

Matplotlib ${ }^{6}$ is a Python 2D plotting library that allows developers to create figures (histograms, bar charts, error charts, etc.). The fifth subtopic added in the collaborative and reflective glossary included six nouns and one adverbial expression, see Table 7.

TABLE 7. MACbioIDi glossary: students' work for the subtopic Matplotlib.

\begin{tabular}{|l|l|l|l|}
\hline $\begin{array}{l}\text { English } \\
\text { Term } \\
\text { (Category) }\end{array}$ & Definition & Pron. & $\begin{array}{l}\text { Spanish (Translation/ } \\
\text { Adaptation) }\end{array}$ \\
\hline Frontend (n) & $\begin{array}{l}\text { The section of software that interacts with an } \\
\text { agent }\end{array}$ & $\begin{array}{l}\text { FRONT- } \\
\text { end }\end{array}$ & front-end \\
\hline Backend (n) & $\begin{array}{l}\text { The section of software that makes some process } \\
\text { with private to the user agent }\end{array}$ & BAK-end & back end \\
\hline $\begin{array}{l}\text { Random / } \\
\text { randomly } \\
\text { (adv) }\end{array}$ & Subjected to no apparent pattern & RAN-dom & $\begin{array}{l}\text { aleatorio / } \\
\text { aleatoriamente }\end{array}$ \\
\hline Switch (n) & $\begin{array}{l}\text { A soft/hard-ware that diverts some data flow to } \\
\text { different directions or regions }\end{array}$ & SWICH & switch \\
\hline Layout (n) & The visual arrangement of something & LEY-aut & layout \\
\hline Plot (n) & To represent graphically & PLOT & $\begin{array}{l}\text { gráfico (n), hacer un } \\
\text { gráfico, plotear, hacer } \\
\text { un plot (v) }\end{array}$ \\
\hline Dataset (n) & A collection of structured data & $\begin{array}{l}\text { DEItaset / conjunto de } \\
\text { datos }\end{array}$ \\
\hline
\end{tabular}

Regarding the bilingual adaptation of the technical terms in the subtopic Matplotlib, it is noteworthy that some words are used in English without there being a Spanish equivalent. This is the case for frontend, backend, switch, and layout. In the case of plot, Spanish offers some equivalents such as gráfico and hacer un gráfico, but the anglicized hybrid expression hacer un plot is also employed. Similar is the case of the non-adapted anglicism dataset and conjunto de datos ('a set of data'), which are interchangeable in Spanish.

\subsubsection{Building QT Framework Vocabulary}

$Q T^{7}$ is defined as a cross-platform software development framework with a technology strategy for developers to create connected devices and applications. It was the sixth subtopic and had a total of five nouns, see Table 8 . As can be observed, the students did not complete the definitions for widget and gadget. During the feedback session on the glossary, students were asked to deliver instant definitions for these two terms to check whether they understood the meanings. Although the definitions uttered in the classroom followed a correct and comprehensible format, students did not include them in the glossary ("TO BE DONE BY SS", marked in Table 8). We underline that the purpose here has been to maintain every table in its original form, as completed by the ESP participants (the reader can also notice a typo in the definition of the glossary entry driver).

$6 \quad$ More information on the Matplotlib website at https://matplotlib.org.

7 The $Q T$ website can be accessed here: https://www.qt.io 
TABLE 8. MACbioIDi Glossary: Students' work for the subtopic QT framework.

\begin{tabular}{|l|l|l|l|}
\hline $\begin{array}{l}\text { English Term } \\
\text { (Category) }\end{array}$ & Definition & Pron. & $\begin{array}{l}\text { Spanish (Translation/ } \\
\text { Adaptation) }\end{array}$ \\
\hline Driver (n) & $\begin{array}{l}\text { A piece of software that directs a particular } \\
\text { piece of harware }\end{array}$ & DRAI-ver & driver \\
\hline Feedback (n) & $\begin{array}{l}\text { The process of using the output of a function as } \\
\text { its own input }\end{array}$ & FID-bak & feedback / realimentación \\
\hline Widget & TO BE DONE BY SS! & WID-yet & widget / asistente \\
\hline Gadget & TO BE DONE BY SS! & GAD-yet & gadget \\
\hline Slot (n) & A physical or logical space to insert something & SLOT & slot \\
\hline
\end{tabular}

Regarding the bilingual adaptation, non-adapted English terms are employed in this subtopic. The technical terms driver, gadget and slot do not have an equivalent term in Spanish, while feedback can also be rendered as retroalimentación, and widget as asistente.

\subsubsection{Building VTKVocabulary}

Finally, the acronym $V T K,{ }^{8}$ which stands for the Visualization Toolkit, is an open-source software package used worldwide by developers to work with computer graphics and show scientific data. This last subtopic included six nouns and a verb, see Table 9. Students noted that he expression plot was common to two subtopics, VTK and Matplotlib.

TABLE 9. MACbioIDi glossary: students' work for the subtopic VTK.

\begin{tabular}{|l|l|l|l|}
\hline $\begin{array}{l}\text { English } \\
\text { Term (Cat- } \\
\text { egory) }\end{array}$ & Definition & Pron. & $\begin{array}{l}\text { Spanish (Translation/ } \\
\text { Adaptation) }\end{array}$ \\
\hline Pipeline (n) & $\begin{array}{l}\text { Sequential chaining of command inputs and } \\
\text { outputs }\end{array}$ & $\begin{array}{l}\text { PAIP- } \\
\text { lain }\end{array}$ & pipeline \\
\hline Binding (v) & $\begin{array}{l}\text { To associate a value with a parameter (or pos- } \\
\text { sible input "field") }\end{array}$ & $\begin{array}{l}\text { BAIN- } \\
\text { ding }\end{array}$ & $\begin{array}{l}\text { enlazar / vincular / bind- } \\
\text { ing / hacer un bind }\end{array}$ \\
\hline $\begin{array}{l}\text { User guide } \\
\text { (n) }\end{array}$ & $\begin{array}{l}\text { A manual used to familiarize a user with a } \\
\text { product }\end{array}$ & $\begin{array}{l}\text { U-ser } \\
\text { GAID }\end{array}$ & guía de usuario \\
\hline Mapper (n) & $\begin{array}{l}\text { A function to bind a set of input values to a } \\
\text { corresponding set of output fields }\end{array}$ & MAP-er & mapear \\
\hline $\begin{array}{l}\text { Keyboard } \\
\text { (n) }\end{array}$ & $\begin{array}{l}\text { A physical device that allows people to type } \\
\text { characters into a computer }\end{array}$ & KI-bord & teclado \\
\hline Plot (n) & [Duplicate: look up] & $\begin{array}{l}\text { gráfico (n) / hacer un } \\
\text { gráfico / plotear / hacer } \\
\text { un plot (v) }\end{array}$ \\
\hline Binding (n) & [Duplicate: look up] & $\begin{array}{l}\text { BAIN- } \\
\text { ding }\end{array}$ & $\begin{array}{l}\text { enlazar / vincular / } \\
\text { binding / hacer un bind }\end{array}$ \\
\hline
\end{tabular}

8 The $V T K$ website is https://www.vtk.org 
Regarding the bilingual adaptation, some anglicisms are also present in the subtopic of VTK. This is the case for the non-adapted anglicism pipeline, which has no Spanish equivalent, and binding, which co-exists with other Spanish terms such as enlazar ('bind') and vincular ('link'). Anglicized hybrid expressions are also employed: hacer un bind and hacer un plot. The term mapear ('to map out') is also a hybrid derivational term, which combines the English stem map with the Spanish verbal suffix -ear.

\subsection{Research Question 3}

RQ3. What examples of ESP vocabulary have students used productively in lifelong learning education?

The ESP participants of this study actively generated receptive and useful vocabulary applied to their professional fields. On the one hand, current expressions extracted from the formative MACbioIDi wiki were reviewed by learners as vocabulary they already use or can use in their professional field. On the other hand, and with the intention of promoting lifelong learning education, these postgraduate students implemented similar learning strategies for their course content, highlighting key ESP terms and acronyms they used for their master's theses. As a result, their use of ESP expressions during their coursework produced satisfactory collocations in written production, as it can be seen in the abstracts that they produced for their theses. Figure 4 shows two examples of this type of language and its accurate production; it includes the use of key concepts, acronyms and academic expressions that have been underlined.

Abstract 1: Nowadays Optical Camera Communication's (OCC) links have increased its relevance within the Visible Light Communication's (VLC) field. The main ambition that drives this research is the development of end user applications that rely on lowcost embedded cameras as receivers. However, this recent technology faces a variety of challenges such as transmitter detection, packet synchronization, and channel estimation. In this work, a novel modulation scheme based on RGB LED sources is presented to address these issues.

Abstract 2: Functional verification of digital systems is often an arduous task due to the high number of tests applicable to a particular design. To ease this process, different methodologies have been proposed by Electronic Design Automation (EDA) companies, one of those being the Universal Verification Methodology (UVM). This methodology uses the System Verilog Hardware Description Language (HDL), allowing the use of object-oriented programming paradigms in verification. [...] This project represents one of the first attempts at perusing the UVM Framework, an immature technology in its early stages of adoption, for the verification of a commercial intellectual property. Once the verification environment was completed, an evaluation of the advantages that the $U V M$ Framework provides compared to standalone development was made, showing promising results.

FigURE 4. Examples of ESP vocabulary used in students' course projects. 


\subsection{General Discussion}

Considering the three learning dimensions at work, as proposed by Illeris (2010) content, motivation and interaction - the study presented here originates in a lifelong learning environment which involves students' examination of workplace lexis in the field of Telecommunications Engineering and ICT. Learners relied on authentic material and interacted with each other and their teacher with the aim of following their interests and being trained for their current workplace situations. Their professional English context (ESP) was experienced as a factor affecting their lifelong learning approach.

Using the MACbioIDi bilingual glossary, the students were able to reflect on the variety of ESP expressions used in their research areas and workplace (Rutherford 2017). At the same time, the MACbioIDi glossary served as a model for students to implement similar strategies to activate the vocabulary related to the course content, paying attention not only to the word, its definition and accurate pronunciation, but also to its use and collocations. By being exposed to second language input, second language learners can be encouraged to achieve the desired language output by means of an interactionist communicative standpoint, which, we would add, can be both reflective and self-directed, especially when dealing with higher education learners (Ardeo González 2016; Elgort 2018).

The MACbioIDi project glossary and the specific content of the course can be evaluated as a productive approach for learners to update and activate their general and specific vocabulary. This study has been designed to manage learners' study areas with the intention of responding to their professional needs by allowing them to recognize and apply new ESP vocabulary consciously, productively, and accurately. Identifying the grammatical function of a term and providing its definition can also improve syntactic and collocational skills. This, in turn, facilitates the correct use of ESP lexis in students' abstracts, reports and other professional projects. Equally, producing correctly pronounced utterances can increase the impact of their spoken interactions.

Finally, we should also stress the interactional aspect of the project. Learners' and teachers' in higher education require a high degree of motivation and both active and passive interaction. These go hand-in-hand with individual learning strategies and determined collaborative teams (Ardeo González 2016; Ng and Ng 2015). Not only have our learners been trained in identifying and producing ESP lexis, but they have also applied ESP content to their professional areas in a lifelong learning environment. This has also increased their awareness of the active roles and skills required in their workplaces.

\section{Conclusion}

Exploring the bilingual, collaborative MACbioIDi glossary has served as a tool to combine autonomous learning and develop collaborative learning and vocabulary learning strategies which allow participants to adapt their knowledge of terminology and help them express themselves accurately in written and oral modes. The terms initially added to the glossary were originally from the MACbioIDi project. Our intention was to expand the European project with the exploration of how Telecommunications Engineering students identify and 
use the expressions selected in the seven ICT domains of GitHub, Building 3D Slicer, Python, PythonNumpy, Matplotlib, QT framework and VTK.

The results demonstrate that the glossary was effectively completed, while relying on the settings of both formal and informal education. Furthermore, the international context of English as a Lingua Franca was also explored through the identification and examination of anglicisms used in Spanish. The students' application of ESP vocabulary in the course project has been successfully achieved: their final abstracts and projects exhibit sufficient proficiency that links their professional fields with global English in lifelong learning education. These students used not only the expressions provided in the glossary, and during the 15 weeks of the course, but also added other specific terms and abbreviations or acronyms extracted from other scientific, digital and academic sources, such as academic papers and specialized forums related to their individual course projects.

It should be noted that the students' communication skills have been attested by their precise and accurate use of technical terms in the glossary and abstracts. Students have also gained awareness and familiarity with ESP terminology, which will be helpful throughout their professional careers, especially considering the fact that this master's degree is meant to prepare them for the labour market. The example of digital ubiquitous lifelong learning presented in this research facilitated the suitable use of contextualized present-day terminology that not only benefits lifelong learners and international professionals (telecommunications engineers, in this particular case), but it also allows them to connect with global and challenging workplace situations.

\section{Acknowledgements}

We would like to thank the students who took part in this research for their active and reflective thoughts and their committed responses during the study.

\section{References}

Alcaraz Varó, Enrique. 2000. El inglés profesional y académico. Madrid: Alianza Editorial.

Ardeo González, Jose Miguel. 2016. "Learning Motivation and Strategies of ESP University Students.” LFE: Revista de Lenguas para Fines Especificos 22 (1): 141-69.

Belcher, Diane D. "English for Specific Purposes: Teaching to Perceived Needs and Imagined Futures in Worlds of Work, Study, and Everyday Life.” TESOL Quarterly 40 (1): 133-56. https://doi.org/10 $.2307 / 40264514$.

Bourn, Douglas. 2018. Understanding Global Skills for 21st Century Professions. Cham: Palgrave Macmillan. Brock-Utne, Birgit. 2016. "English as the Language of Science and Technology." In Human Rights in Language and STEM Education, edited by Zehlia Babaci-Wihite, 109-27. Rotterdam, Boston, Taipei: Sense.

Conole, Gráinne, and Pascual Pérez Paredes. "An Analysis of Adult Language Learning in Informal Settings and the Role of Mobile Learning." In Mobile and Ubiquitous Learning, edited by Shengquan Yu, Mohamed Ally, Avgoustos Tsinakos, 45-57. Singapore: Springer.

Cope, Bill, and Mary Kalantzis, eds. 2017. e-Learning Ecologies: Principles for New Learning and Assessment. New York and London: Routledge.

Crespo-Fernández, Eliecer, and Carmen Luján-García. 2017. "Anglicisms and Word Axiology in Homosexual Language.” Revista Española de Lingüistica Aplicada 30 (1): 74-103. https://doi.org/10 $.1075 /$ resla.30.1.04cre. 
—. 2018. Anglicismos sexuales en español. El inglés como recurso eufemistico y disfemistico en la comunicación virtual. Granada: Comares.

Crystal, David. 2012. English as a Global Language. Cambridge: Cambridge University Press.

Dewey, Martin. 2014. "Pedagogic Criticality and English as a Lingua Franca." Atlantis 36 (2): 11-30.

Duff, Patricia A. 2017. "Language Socialization, Higher Education, and Work." In Language Socialization. Encyclopedia of Language and Education, 3rd ed., edited by Patricia A. Duff and Stephen May, 1-18. Cham: Springer. https://doi.org/10.1007/978-3-319-02327-4_19-1.

Elgort, Irina. 2018. "Teaching/Developing Vocabulary Using ICTs and Digital Resources." The TESOL Encyclopedia of English Language Teaching. 1-15. https://doi.org/10.1002/9781118784235.eelt0735.

Elsafi, Abdelwahed. 2018. "Formal and Informal Learning Using Mobile Technology." In Mobile and Ubiquitous Learning, edited by Shengquan Yu, Mohamed Ally, Avgoustos Tsinakos, 177-89. Singapore: Springer.

Enos, Michael D., Marijke Thamm Kehrhahn, and Alexandra Bell. 2003. "Informal Learning and the Transfer of Learning: How Managers Develop Proficiency.” Human Resource Development Quarterly 14 (4): 369-87.

Feez, Susan, and Frances Quinn. 2017. "Teaching the Distinctive Language of Science: An Integrated and Scaffolded Approach for Pre-Service Teachers.” Teaching and Teacher Education 65: 192-204. https:// doi.org/10.1016/j.tate.2017.03.019.

Ferguson, Gibson. 2007. "The Global Spread of English, Scientific Communication and ESP: Questions of Equity, Access and Domain Loss." Ibérica: Revista de la Asociación Europea de Lenguas para Fines Específicos 13: 7-38.

Fraiberg, Steven. 2018. "Multilingual and Multimodal Practices at a Global Startup: Toward a Spatial Approach to Language and Literacy in Professional Contexts." English for Specific Purposes 51: 55-68. https://doi.org/10.1016/j.esp.2018.03.003.

García-Sánchez, Soraya. 2016. "Ubiquitous Interaction for ESP Distance and Blended Learners." Journal of Applied Research in Higher Education 8 (4): 489-503.

—. 2017. "Collaborative Ubiquitous Learning: A 21st Century Approach for (In)Formal Scenarios." In Informal Learning: Perspectives, Challenges and Opportunities, edited by Stephen Rutherford, 57-70. New York: Nova Science Publishers.

García-Sánchez, Soraya, and Nicholas C. Burbules. 2017. "A Revision of Activity Theory to Foster Communicative Twenty-First-Century Skills.” International Journal of Learning: Annual Review 24 (1): 1-12. https://doi.org/10.18848/1447-9494/CGP/v24i01/1-12.

García-Sánchez, Soraya, and Carmen Luján-García. "Ubiquitous Knowledge and Experiences to Foster EFL Learning Affordances.” Computer Assisted Language Learning 29 (7): 1169-80. https://doi.org/10 $.1080 / 09588221.2016 .1176047$.

García Morales, María Goretti, Carmen Luján-García, Isabel González Cruz, and María Jesús Rodríguez Medina. 2016. La presencia del inglés en la publicidad televisiva española (2013-2015). Madrid: Síntesis.

Illeris, Knud. 2010. The Fundamentals of Workplace Learning: Understanding How People Learn in Working Life. Abingdon. New York: Routledge.

Jenkins, Jennifer. 2015. "Repositioning English and Multilingualism in English as a Lingua Franca." Englishes in Practice 2 (3): 49-85. https://doi.org/10.1515/eip-2015-0003.

Kassim, Hafizoah, and Fatimah Ali. 2010. "English Communicative Events and Skills Needed at the Workplace: Feedback from the Industry.” English for Specific Purposes 29 (3): 168-82. https://doi.org /10.1016/j.esp.2009.10.002.

Kennedy, Chris. 2012. "ESP Projects, English as a Global Language, and the Challenge of Change." Ibérica, Revista de la Asociación Europea de Lenguas para Fines Especificos 24: 43-54.

Latchem, Colin. 2016. "Learning Technology and Lifelong Informal, Self-directed, and Non-formal Learning." In The Wiley Handbook of Learning Technology, edited by Nick Rushby and Dan Surry, 180-99. West Sussex: John Wiley \& Sons.

López Zurita, Paloma. 2018. "El uso de anglicismos en el contexto del vocabulario academico de Marketing." Onomázein 39: 114-39. https://doi.org/10.7764/onomazein.39.06. 
Loveless, Avril, and Ben Williamson. 2013. Learning Identities in a Digital Age: Rethinking Creativity, Education and Technology. Abingdon, New York: Routledge.

Luján García, Carmen Isabel. 2015. "Lexical Anglicisms: An Analysis of Commercials Addressed to Young Children on Four Television Channels in Spain." Onomazein 32: 289-304. https://doi.org/10.7764 /onomazein.32.17.

- 2017. "Analysis of the Presence of Anglicisms in a Spanish Internet Forum: Some Terms from the Fields of Fashion, Beauty and Leisure." Alicante Journal of English Studies 30: 277-300. https://doi.org /10.14198/raei.2017.30.10.

MedTec4SusDev.org - MACbioIDi.eu. 2020. “Medical Technology for Sustainable Development.” https:// mt4sd.ulpgc.es.

McIntosh, Kyle, Ulla Connor, and Esen Gokpinar-Shelton. 2017. "What Intercultural Rhetoric Can Bring to EAP/ESP Writing Studies in an English as A Lingua Franca World.” Journal of English for Academic Purposes 29: 12-20. https://doi.org/10.1016/j.jeap.2017.09.001.

McKay, Sandra Lee, and Wendy D. Bokhorst-Heng. 2017. International English in Its Sociolinguistic Contexts: Towards A Socially Sensitive EIL Pedagogy. New York, Abingdon: Routledge.

Mishan, Freda. 2004. "Authenticating Corpora for Language Learning: A Problem and Its Resolution." ELT Journal 58 (3): 219-27. https://doi.org/10.1093/elt/58.3.219.

Navickienè, Violeta, Dalia Kavaliauskienè, and Sigita Pevcevičiūtè. 2015. "Aspects of ESP Learning Motivation in Tertiary Education." Tiltai 71 (2): 97-108. https://doi.org/10.15181/tbb.v71i2.1103.

$\mathrm{Ng}$, Chiew Fen, and Poh Kiat Ng. 2015. "A Review of Intrinsic and Extrinsic Motivations of ESL Learners." International Journal of Languages, Literature and Linguistics 1 (2): 98-105. https://doi.org /10.7763/IJLLL.2015.V1.20.

Pennycook, Alastair. 2017. The Cultural Politics of English as an International Language. New York: Routledge.

Peters, Elke, and Stuart Webb. 2018. "Incidental Vocabulary Acquisition Through Viewing L2 Television and Factors that Affect Learning." Studies in Second Language Acquisition 40 (3): 551-77. https://doi .org/10.1017/S0272263117000407.

Pulcini, Virginia, Cristiano Furiassi, and Félix Rodríguez González. 2012. "The Lexical Influence of English on European Languages." In The Anglicization of European Lexis, edited by Cristiano Furiassi, Virginia Pulcini and Félix Rodríguez González, 1-26. Amsterdam: John Benjamins.

Rienties, Bart, and Ian Kinchin. "Understanding (In)formal Learning in an Academic Development Programme: A Social Network Perspective." Teaching and Teacher Education 39: 123-35. https:/doi .org/10.1016/j.tate.2014.01.004.

Rodríguez González, Félix. 1994. "Anglicismos en el argot de la droga.” Atlantis 16 (1-2): 179-216.

—. 2012. "Anglicismos en el mundo del deporte: variación lingüística y sociolingüística." Boletín de la Real Academia Española XCII (CCCVI): 285-309.

Rodríguez-Medina, María Jesús. "An Approach to the Study of the Use of English in the Activities of Spanish Gyms." Spanish in Context 13 (1): 128-48. https://doi.org/10.1075/sic.13.1.06rod.

Rutherford, Stephen. "Perspectives, Challenges, and Opportunities of Informal Learning." In Informal Learning: Perspectives, Challenges and Opportunities, edited by Stephen Rutherford, 1-20. New York: Nova Science Publishers.

Tejedor Martínez, Cristina. "The Influence of the English Language on the Description of Cosmetic Products." Alicante Journal of English Studies: 303-29. https://doi.org/10.14198/raei.2017.30.11.

Yano, Yasukata. 2009. "English as an International Lingua Franca: From Societal to Individual." World Englishes 28 (2): 246-55. https://doi.org/10.1111/j.1467-971X.2009. 